\title{
Effect of concentration difference of chloride ions on the corrosion of steel bar
}

\author{
Hai-Bin Shu', a, Yi-Lin Song ${ }^{2, b}$, Jun-Zhe LIU ${ }^{3, c}$ \\ Faculty of Architectural, Civil Engineering And Environment, Ningbo University, Ningbo, 315211, \\ China \\ pualbinbin@163.com
}

\begin{abstract}
Keyword: Reinforced concrete, Macro cell corrosion, Chlorine ion concentration difference, Area ratio of cathode and anode

Abstrct. Corroded area rate, weight loss rate and the macro cell corrosion of rebars in concrete subjected to concentration difference of chloride ion was investigated. In order to evaluate the corrosion mechanism of rebars, the corrosion behaviour of rebars in concrete under different chloride concentration difference were contrasted with that of the concrete contaminated with uniform chlorine ion concentration. Results indicated that compared with the concrete contaminated with uniform chlorine ion concentration, the rebars corroded area are higher in concrete under different chloride ion concentration difference, and the rebars corroded area are also higher in concrete in large cathode small anode contrasted with that of the condition in large cathode small anode. Furthermore, the both of rebars corroded area is more serious than uniform chlorine ion concentration.
\end{abstract}

\section{introduction}

Chloride erosion is one of the major factors leading to corrosion of reinforced concrete structures, durability decrease, which is present in a great number of existing projects. In winter, de-icing salt, the main ingredient is chlorine ion, is often needed to ensure smooth road in the northern areas of China[1], which leads to a large amount of chlorine ions penetrate the concrete, causing reinforcement corrosion; in coastal areas, offshore construction prolonged exposure to sea water, inevitably result in exposure to seawater erosion of chloride ions[2], causing chloride ions into the concrete caused by reinforcement corrosion. There are also many structures suffered from chloride ion in other countries[3,4]. Furthermore, in the process of concrete invasion, there must be some chlorine ion concentration difference.

Most studies have focused on uniform concentration chloride ion corrosion of reinforced concrete[5], but the corrosion of reinforced concrete under the chloride ion concentration difference is rarely taking into account. Therefore, this paper comprehensive evaluate the corrosion mechanism of steel under chloride ions concentration difference by studying corrosion area rate, weight loss rate and macrocell corrosion of steel bars.

\section{experimental}

\section{preparation}

Select a diameter of $13 \mathrm{~mm}$, a length of $390 \mathrm{~mm}$ round bar, which was shaved passive film by sodium citrate. Porland Cement $\mathrm{P} \bullet \mathrm{O} 42$. 5 was used. The fine aggregate was a river sand with the fineness modulus of 2. 27. The coarse aggregate was crushed limestone with the maximum size of $20 \mathrm{~mm}$. Table 1 shows the mix proportion of concrete. 
Table 1 Mix proportion of concrete

\begin{tabular}{|l|l|l|l|l|l|l|l|}
\hline \multicolumn{3}{|l|}{ Content of materials/( $\left.\mathrm{kg} \cdot \mathrm{m}^{-3}\right)$} & Mix parameter \\
\hline Cement & Sand & $\begin{array}{l}\text { Coarse } \\
\text { aggregate }\end{array}$ & Water & $\begin{array}{l}\text { Water-sement } \\
\text { ratio }\end{array}$ & $\begin{array}{l}\text { Sand } \\
\text { ratio(\%) }\end{array}$ & $\begin{array}{l}\text { Slump } \\
(\mathrm{cm})\end{array}$ & $\begin{array}{l}\text { Air } \\
\text { content }(\%)\end{array}$ \\
\hline 300 & 760 & 1080 & 180 & 0.6 & 41 & 16 & 4 \\
\hline
\end{tabular}

The size of specimen was $100 \mathrm{~mm} \times 100 \mathrm{~mm} \times 400 \mathrm{~mm}$. The content of chloride ions in concrete was $0 \mathrm{~kg} / \mathrm{m}^{3} 、 1 \mathrm{~kg} / \mathrm{m}^{3} 、 2 \mathrm{~kg} / \mathrm{m}^{3} 、 3 \mathrm{~kg} / \mathrm{m}^{3}$ and $4 \mathrm{~kg} / \mathrm{m}^{3}$. After considering the cathode and anode area ratio impact to macro cell corrosion, the area ratio of cathode and anode is designed at 3:1. Fig.1 shows the concentration difference of chloride ions in concrete.

After demoulding, the steel bars in concrete was covered with epoxy in order to prevent steel corrosion exposing to the air. the specimens were accelerated corrosion at $60^{\circ} \mathrm{C}$ and $\mathrm{RH} 98 \%$ after cured at $20^{\circ} \mathrm{C}$ and $\mathrm{RH} 60 \%$ for $28 \mathrm{~d}$.

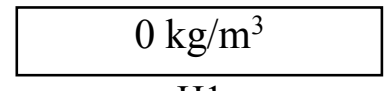

$\mathrm{H} 1$
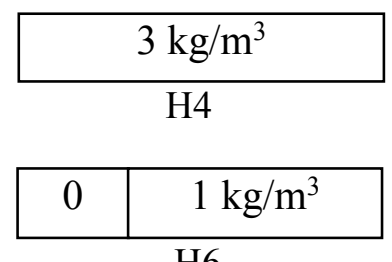

H6

\begin{tabular}{|l|c|}
\hline 0 & $4 \mathrm{~kg} / \mathrm{m}^{3}$ \\
\hline
\end{tabular}

\begin{tabular}{|l|c|}
\hline 1 & $0 \mathrm{~kg} / \mathrm{m}^{3}$ \\
\hline
\end{tabular}

\begin{tabular}{|l|c|}
\hline 4 & $0 \mathrm{~kg} / \mathrm{m}^{3}$ \\
\hline
\end{tabular}

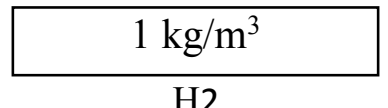

$\mathrm{H} 2$

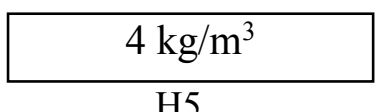

H5

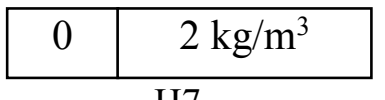

$\mathrm{H} 7$

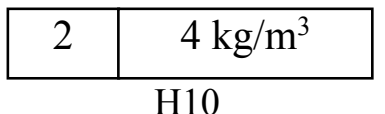

\begin{tabular}{|l|l|}
\hline 2 & $0 \mathrm{~kg} / \mathrm{m}^{3}$ \\
\hline
\end{tabular}

H12

\begin{tabular}{|l|c|}
\hline 4 & $2 \mathrm{~kg} / \mathrm{m}^{3}$ \\
\hline
\end{tabular}

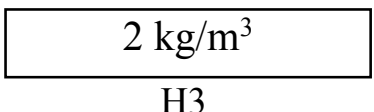

$\mathrm{H} 3$

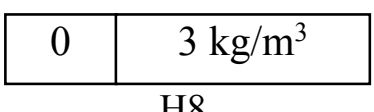

$\mathrm{H} 8$

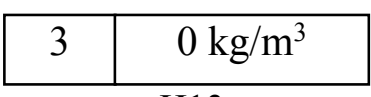

H13

Fig 1 concentration difference of chloride ions in concrete $\left(\mathrm{kg} / \mathrm{m}^{3}\right)$

\section{The determination method of corrosion area rate and weight loss rate}

The corrosion area rate and weight loss rate were tested every three months, which was adjusted according to JCI-SC1.

\section{Experimental results and analysis}

\section{The effect of steel corrosion on uniform chloride ions concentration}

Fig.2 shows the corrosion area rate on sample $\mathrm{H} 1 \sim \mathrm{H} 5$. When the chloride ion content is $4 \mathrm{~kg} /$ $\mathrm{m}^{3}$, the rate of corrosion area up to $68.79 \%$, and the upper portion of each specimen steel corrosion is serious than the lower portion. The sample $\mathrm{H} 1 \sim \mathrm{H} 5$ can be seen that the difference rate of upper steel and lower steel tends to zero with increasing chloride concentration. The corrosion area rate on sample $\mathrm{H} 2$ reached a maximum of $46.98 \%$, while the corrosion area rate on sample H1 was only 7 . $8 \%$.

Fig. 3 shows the weight loss rate on sample $\mathrm{H} 1 \sim \mathrm{H} 5$. When the chloride ion content is $4 \mathrm{~kg} / \mathrm{m}^{3}$, the weight loss rate up to $18.65 \%$, and the upper portion of each specimen steel corrosion is serious than the lower portion. $\mathrm{H} 1 \sim \mathrm{H} 5$ can be seen that the difference rate of upper steel and lower steel tends to zero with increasing chloride concentration. The weight loss rate on sample $\mathrm{H} 2$ reached a 
maximum of $32.61 \%$, while the corrosion area rate on sample H5 was only $5.77 \%$.

The steel corrosion of sample H10 and H15 were more serious than H5, while the chloride ion content of $\mathrm{H} 10$ and $\mathrm{H} 15$ were less than that of H5. On the other word, the steel corrosion under the concentration difference chloride ion was more serious than steel corrosion under the uniform concentration chloride ion.

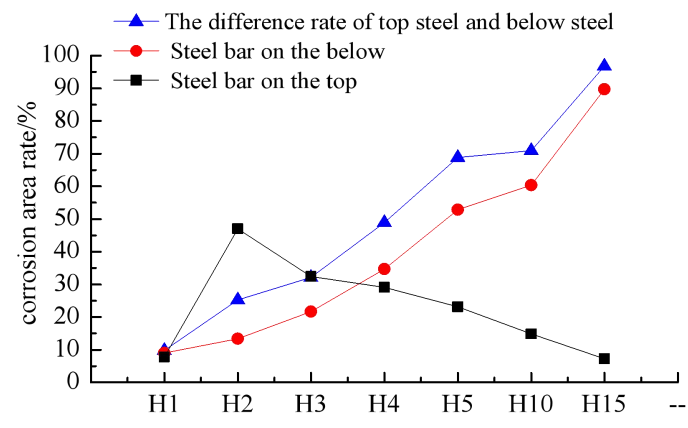

Fig.2 the corrosion area rate

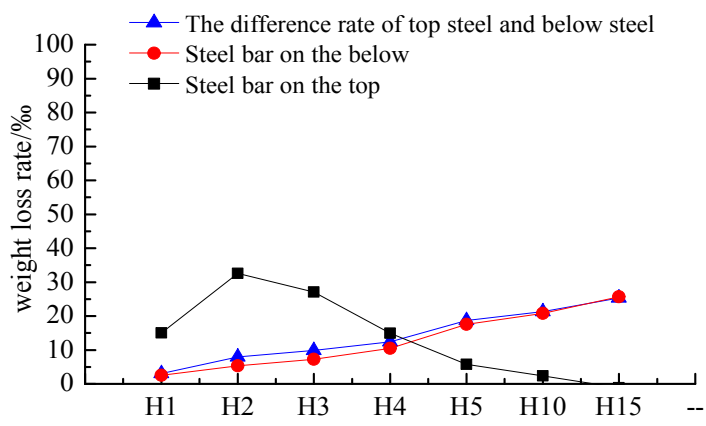

Fig.3 the weight loss rate

Under normal circumstances, the steel surface oxide film is formed to protect steel from corrosion in the concrete alkaline pore solution. The $\mathrm{pH}$ of the concrete pore solution will decrease while chlorine ions into the concrete, causing the steel surface passive film be dissolved no longer. Since the destruction of the passive film, the steel surface appears potential difference, forming the anode and cathode, resulting in the macro cell corrosion begins. The more the numbers of chloride ion of concrete pore solution, the more obvious ions transporting are, accelerating steel depolarization.

\section{The effect of macrocell corrosion of steel on chloride ion concentration difference}

Fig.4 shows the corrosion area rate on chloride ion concentration difference. Because few of steel surface is corroded on the unincorporated chloride side when both sides of the specimen establish a concentration difference of chloride ions. That means, the corrosion area rate represents the side of which incorporation of chloride ion. The steel corrosion is the most serious when the area ratio of cathode and anode is designed at $3: 1$. Even the chloride ion content was $1 \mathrm{~kg} / \mathrm{m}^{3}$, steel corrosion rate reached $42.56 \%$, and the steel corrosion rate was $99.44 \%$ when chloride content is $4 \mathrm{~kg} / \mathrm{m}^{3}$. And also the steel corrosion in the area ratio of cathode and anode at 1:3 was more serious than that of the area ratio of cathode and anode at $1: 1$. the chloride ion content was $1 \mathrm{~kg} / \mathrm{m}^{3}$, steel corrosion rate was $27.71 \%$, and the steel corrosion rate was $75.64 \%$ when chloride content was $4 \mathrm{~kg} / \mathrm{m}^{3}$. While on the condition of uniform chloride ions concentration, the chloride ion content was $1 \mathrm{~kg} / \mathrm{m}^{3}$, steel corrosion rate was only $21.27 \%$, and the steel corrosion rate was $68.79 \%$ when chloride content was $4 \mathrm{~kg} / \mathrm{m}^{3}$.

Fig. 5 shows the weight loss rate on chloride ion concentration difference. The weight loss rate represents the side of which incorporation of chloride ion. The steel corrosion was the most serious

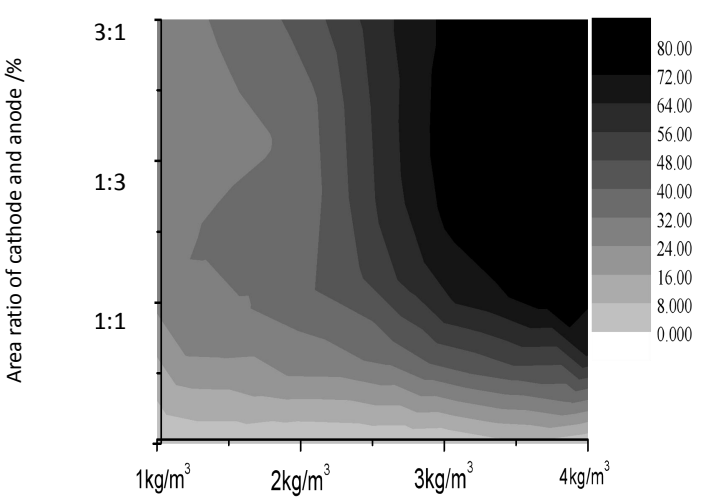

Fig. 4 the corrosion area rate

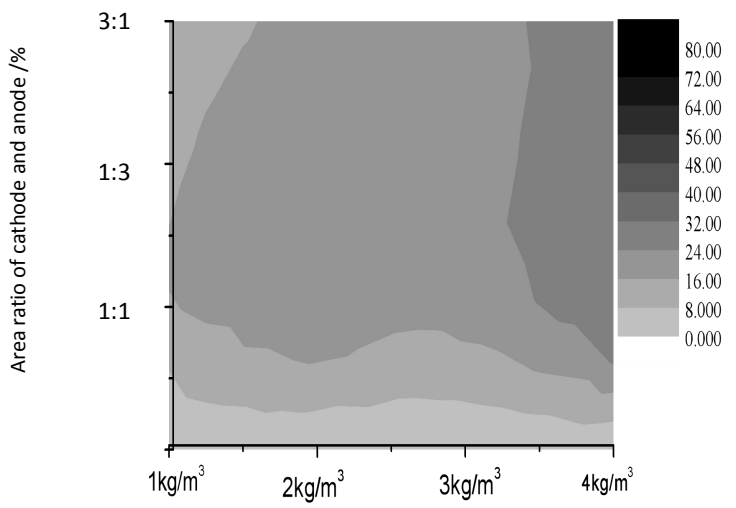

Fig. 5 the weight loss rate 
when the area ratio of cathode and anode was designed at 3:1. Even the chloride ion content was $1 \mathrm{~kg} / \mathrm{m}^{3}$, the weight loss rate reached $18.58 \%$, and the weight loss rate was $37.8 \%$ when chloride content was $4 \mathrm{~kg} / \mathrm{m}^{3}$. And also the steel corrosion in the area ratio of cathode and anode at 1:3 was more serious than that of the area ratio of cathode and anode at 1:1. the chloride ion content was $1 \mathrm{~kg} / \mathrm{m}^{3}$, the weight loss rate was $14.99 \%$, and the weight loss rate was $27.19 \%$ when chloride content was $4 \mathrm{~kg} / \mathrm{m}^{3}$. While on the condition of uniform chloride ions concentration, the chloride ion content was $1 \mathrm{~kg} / \mathrm{m}^{3}$, the weight loss rate was only $11.94 \%$, and the weight loss rate was 26 . $65 \%$ when chloride content was $4 \mathrm{~kg} / \mathrm{m}^{3}$.

According to the weight loss rate and the steel corrosion rate, little anode and great cathode was more susceptible to corrosion than that of great anode and little cathode. and both of them were easier corrosion than the uniform chloride ions concentration. It can be seen that it showed uniform corrosion under the condition of the uniform chloride ion concentration, it showed pit corrosion under the condition of the chloride ions concentration difference. If there are chloride ions of high concentration in the concrete, it often shows uniform corrosion.

Steel corrosion become faster if the anode area was small compared to the cathode. The reason was that the anode lose electrons, forming a small corroded area, resulting in the corrosion current become large, and the large cathodic polarization was not easy, so the corrosion accelerated. Galvanic corrosion, the great cathode small anode corrosion, usually presents localized corrosion. The reason was that the corrosion was concentrated on one point, while the surrounding passivation film was not destroyed, it can only be corrosion of vertical depth, forming a small area of the anode and a large area of the cathode on steel surface. That called pit corrosion.

Compared to the large cathode small anode, the corrosion current of the large anode and small cathode was smaller, resulting a lower corrosion in this condition. But the corrosion current of the large anode and small cathode was faster than that of uniform chloride ion concentration. That means the corrosion of the large anode and small cathode was more serious than that of uniform chloride ion concentration. And, Even in the case of uniform chloride ion concentration may also form a large cathode small anode corrosion because of rough steel surface, Uneven concrete vibrators etc.

\section{conclusions}

1) Steel corrosion in concrete showed a uniform corrosion under the same concentration of chloride ions, and the higher of concentration of chloride ion the more significant of uniform corrosion.

2) Steel corrosion of chlorine ion concentration difference was more serious than that of uniform chlorine ion corrosion. and the higher of concentration difference of chloride ion the more significant of pit corrosion.

3) The corrosion of the large anode and small cathode was faster than that of the small anode and large cathode. and both of them were more serious than a uniform chloride ion concentration.

\section{References}

[1] Yong zhou, Yu zuo. Surface films on plasma nitrided stainless steel subjected to passivation treatments[J]. Applied Surface Science. 2015(353):924-932

[2] Hailong Ye, Ye Tian, Nanguo Jin, Xianyu Jin, Chuanqing Fu. Influence of cracking on chloride diffusivity and moisture influential depth in concrete subjected to simulated environmental conditions [J]. Construction and Building Materials. 2013, 47:66-79.

[3] Aït-Mokhtar, R. Belarbi, F. Benboudjema. Experimental investigation of the variability of concrete durability properties[J]. Cement and Concrete Research. 2013, 45: 21-36.

[4] Isabel Fernandes, Fernando Noronha, Madalena Teles. Microscopic analysis of alkali-aggregate reaction products in a 50-year-old concrete[J]. Materials Characterization. 2004, 53:295-306.

[5] Morris W, Vico A. Choride induced corrosion of reinforcing steel evaluated by concrete resistivity measurements[J]. Electrochimica Acta. 2004 25(49):4447-4453. 